Journal of Sustainable Development of Transport and Logistics

journal home page: http://jsdtl.sciview.net

\title{
Analysis of the interaction of participants freight forwarding system
}

\section{Pavlo Popovych *, Svitlana Shyriaieva **, Ninel Selivanova ***}

* Ternopil Ivan Pul'uj National Technical University, 56 Ruska str., 46001 Ternopil, Ukraine

Dr, Professor, Department of Transport Technology

** National Transport University,

1, Omelyanovych-Pavlenko str., 01010, Kyiv, Ukraine

PhD, Professor, Department of Transport Technology

*** National Transport University,

1, Omelyanovych-Pavlenko str., 01010, Kyiv, Ukraine

Senior Lecturer, Department of Transport Technology

\section{open $(2$ access (c) $d o$ )}

\section{Article history:}

Received: October, 2016

1st Revision: October, 2016

Accepted: November, 2016

\section{DOI:}

10.14254/jsdtl.2016.1-1.3

\begin{abstract}
Main goal of this work is the analysis of the interaction of participants of freight forwarding activities. Research methods included analysis of scientific literature, theory of systems and systems analysis, methods of induction and deduction. As sources of information used and applied work of fundamental importance known foreign and local scientists and regulatory and legislative documents of Ukraine for the state transport policy.

In the article the basic interactions of participants of freight forwarding activities. Classified components freight forwarding services. Assign the concept freight forwarding system and its aim. Established element and forms of cooperation in the freight forwarding system.
\end{abstract}

The main task of forwarding companies are organizing, coordinating and ensuring the delivery from shipper to consignee. Freight forwarding company responsible for the timely delivery of the goods on the condition of preservation of the quantity and quality specified time conditions. Currently used methods are uneffective decisionmaking, leading to losses. These circumstances require improvement methodology management of freight forwarding companies. This is possible only using modern mathematical methods and information technologies that will improve the operation of freight forwarding companies.

The article presents a theoretical exposition of the basic processes of interaction between participants in freight forwarding system. The article may be of interest to specialists of freight forwarding companies.

Keywords: freight forwarding system, interaction of participants of the freight forwarding system, processes into the freight forwarding system. 


\section{Introduction}

Process of globalization of markets in the world and the activities of international corporations create conditions for the growth of demand for freight forwarding services. The unique geographical position of Ukraine gives Ukrainian freight forwarders struggle for influence in the market of freight forwarding services, despite the crisis.

The world currently observed on the one hand, globalization, and the other, producers are aspire to nondiversification. Producers give back many functions to outsourcing companies. In this regard, along with carriers, stevedoring, agency, freight companies an important role in the process of transportation is freight-forwarding companies, which at the time interested in increasing their list of services.

The main task of forwarding companies are organizing, coordinating and ensuring the delivery from shipper to consignee. Freight forwarding company is a legal entity, it is responsible for delivering the freight on time, without losing its quality and quantity in a given time conditions. According to the signed contract of freight forwarding services, freight forwarding company must constantly track the location of cargo management decisions that ensure the timely delivery of cargo to coordinate cooperation between different participants of delivery. Currently used methods are uneffective decision-making, leading to losses.

These circumstances require improvement methodology management of freight forwarding company in particular, and freight forwarding system as a whole. This is possible only using modern mathematical methods and informational technologies and will improve the work of forwarding companies.

The object of research in the article is interaction processes of participants in freight forwarding system.

The subject of inquiry is regularity functioning freight forwarding system.

\section{Literature review}

Great contribution to the research of problems of optimization of interaction between different modes of transport, development of transport systems and freight forwarding work made Bahinova V., Balalaev A., Eliseev S., Zubkov V., Ivanov D., Kalinichenko A., Klepikov P., Kozlov P., Kitlyarenko E., Kurenkova P., Lazarev H., Miloslavsky P., Mirotin L., Nagornyy E., Novikov V. Osminina A., Pluzhnikov K., Reser S., Smekhov A. Povorozhenko V., and other scientists.

Proceedings are devoted mainly to the research of the features of the market of transport-forwarding service since its appearance (Nagornyy \& Naumov, 2009), in-depth study of complex service delivery (Naumov, 2009; Jan \& Kiryukhina, 2005; Popovych, 2016; Shevchuk, 2016), defining the role of freight forwarders as the market as a whole and identify a number of problems in the Ukrainian freight forwarding (Hryhorak \& Kotsyuba, 2006; Levkovets, 2003) enterprises. Analyzing the market of logistics services in Ukraine (Hryhorak \& Kotsyuba, 2006), the authors draw conclusions that the main international and domestic freight flows are distributed between foreign freight forwarders.

It should be noted that in scientific works much emphasis on economic issues of forwarding activities. Not enough attention is focused on the analysis of the interaction between the participants place greater focus on forwarding activities. This makes it difficult to identify areas for further research in the area of improving the functioning freight forwarding system.

\section{Research methods}

Methods of study: theory of systems and systems analysis, methods of induction and deduction. As sources of information used and applied work of fundamental importance known foreign and local scientists and regulatory and legislative documents of Ukraine for the state transport policy.

\section{Research results}

Freight forwarding activity exempt from non-core functions of delivery freight to the consumer, including the need to interact with other companies (agents, carriers, etc.).

The legal and organizational basis for freight forwarding activities in Ukraine are governed by regulations, the main ones are: Civil Code of Ukraine; Economic Code of Ukraine; The freight forwarding activities Act of Ukraine; The Transport Act of Ukraine; Foreign Economic Activity Act of Ukraine; The transit of cargo Act of Ukraine, etc.

According to The freight forwarding activity, forwarding activity - business activity is the provision of freight forwarding services on organization and transportation of export, import, transit or other cargo (The Law of Ukraine, 2004).

Also, freight forwarding activities can be characterized as transport activities in the field, covering the full range of operations and service delivery from producer to consumer (Shanova, Popova, \& Gorev, 2011). 
The key document in the provision of freight forwarding services is a contract of freight forwarding. Under this contract the forwarder shall: organize shipping transport and the route is selected by forwarder or customer; obliged to conclude on their own behalf or on behalf of a client contract of carriage; secure sending and receiving of goods; and other duties related to transportation. The agreement of freight forwarding may provide as additional services needed for the delivery (check the quantity and condition of cargo, its loading and unloading, payment of duties, fees and expenses assigned to the client, storage of goods to its receipt at the destination, receiving necessary for export and import documents, customs formalities, etc.) (Jan \& Kiryukhina, 2005).

According to The freight forwarding activities, participants forwarding business is customers, carriers, freight forwarders, transport agents, ports, railway stations, associations and enterprises specialized rail, air, road, river and sea transport, customs brokers and other persons performing work (services) for the carriage of freight (The Law of Ukraine, 2004).

In the process of transporting cargo need to implement a number of additional, related transactions are directly attributable to freight forwarding operations. They perform independent enterprises and organizations, which is the link between the clientele and the carrier and between different modes of transport in cargo handling areas. At present the scope of forwarding activity is increasingly becoming an independent subsector at the junction between the transport and freight forwarding, while integrating with the sphere of transportation services on the one hand, and the production and distribution - on the other. The subject that is defining the market demand for tonnage, was the forwarder. The impact of freight forwarders in recent years strengthened its position in relation to transport and occupies a key position of transport, freight forwarding forming system. Speaking about transport and forwarding system, it is understood that the freight forwarder is a central element in the development of the route and its delivery technologies, forms a complete load of the vehicle and affect pricing. Addressing organized transportation on a large number of areas and working with an unlimited number of cargo, he can have a contractual basis with discount rates of traffic that has a positive effect on the reduction of through freight rates. The concentration of supply in the hands forwarding allows you to maintain demand at slightly less than the proposal "tonnage" of all sectors of the market by a skilled redistribution between the different modes of transport using the free areas, thereby adjusting the seasonal and cyclical ups and downs of demand for freight forwarders services, cargo congestion at crossings.

Freight forwarder organizes and delivers the cargo with systems "door to door" and "just in time", which provide clear and coordinated work of different modes of transport.

Freight forwarding services can be divided into two main types: delivering and shipping. The Elements of freight forwarding services can be classified as follows (Shyriaieva, \& Selivanova, 2014):

1) Transportation Services:

- chartering vehicles;

- transport of cargo;

2) Loading and unloading cargo:

- loading and unloading of transport, including automobile transport, on the stations (ports), on the storage of freight owners;

- cargo handling;

- forming and unforming of unit load;

- repair of transport containers (tare);

- packaging, linking, fastening of cargo;

- loading cargo to the containers and unloading from them;

3) Warehousing:

- storaging of freight;

- sort of cargo;

- create identification code of cargo

- reception and delivery of cargo, checking of quantity, weight, quality of cargo, packaging and tare;

- stocking small loads and making units loads of cargo;

- unstocking unit loads for delivery to consignee;

4) Arrangement and equipping vehicles:

- cleaning waggon, lower hold, carbody and conteiners;

- provision of equipment of packaging for cargo owner;

- equipment of waggones, vehicles, and automobiles: materials for loading and unloading cargo;

5) Registration document reception and delivery of goods:

- registration accompanying inventory, trade and transport, phytosanitary, quarantine, consular and other documentation;

- registration forwarding of goods;

- commercial registration acts shortage, surplus, damage, injury, loss of cargo and containers;

- presentation of goods to be carried in public places and common use at stations (ports) of departure;

- delivery of cargo to the station (port) of destination; 
6) Logistics services:

- distribution services, warehousing, procurement and logistics information;

7) Customs services:

- declaration of goods in customs;

- cargo counseling on issues related to declaration of the goods;

- registration of the cargo customs declaration and related documents for the goods;

- payments for customs duties;

8) Cargo Insurance:

- preparation and contract cargo insurance;

- payment of premiums;

- execution of relevant documents in the insurance case and get him indemnity;

9) Payment and financial services:

- registration and payment for freight service, custom duty, penalties, ect.;

- payment for operations of the cargo delivery, cargo handling, storaging, etc.;

10) Information services:

- informing the consignee (consignor) of the location of cargo arrival to the destination;

- checking location tracking of cargo from point of origin to destination;

- messaging consignee (consignor) of the arrival of empty or loaded vehicle;

- informing the consignor of delivery of cargo to the consignee;

- messaging the consignee (consignor) of the cargo crossing the border;

- messaging the consignee (consignor) about load cargo on the rolling stock or vessel, unload of cargo;

11) Other forwarding services:

- the development and harmonization of technical conditions of loading and securing of cargo;

- search (if necessary) after the expiry of cargo delivery;

- monitoring compliance with the rules of complete shipment;

- remarking goods;

- maintenance and repair of containers;

- renting cars, containers, warehouses, terminals and other facilities for the provision of freight forwarding services;

- consulting;

- outsourcing;

- other services on request.

Subjects of forwarding system are: public authorities (customs and border authorities, judicial authorities, law enforcement bodies, the administration of ports, airports, railways, highways); consumers of services (producers, buyers, intermediaries); service providers (carriers, terminals, freight forwarding company, agents, insurance companies, consulting and leasing companies, associations, surveyors, logistics companies).

Freight forwarding system - is a collection of all the participants, works and services aimed at meeting the needs of transport and forwarding services on organization and transport of export, import, transit or other goods through the interaction of all elements forwarding system.

The aim functioning forwarding system is a comprehensive optimization of freight forwarding services and the minimization of the costs incurred.

Foreign experience shows that implementing the principles of a systematic approach to the practice of transport - forwarding companies increase their efficiency by $20-35 \%$. The systems approach, first of all, must appear in a clear integration and interaction of all elements of the transport process.

Basis forwarding system are different production, transportation, trade, information, financial and other subsystems that operate primarily on the basis of commodity-money relations. Formation of any subsystem must determine the integrity of the system. Each element forwarding system to some extent independent and has its own purpose. It aims to achieve a common goal for the system, which is the main limitation of costeffective, efficient and reliable operation.

All processes of management and organization of the transport process must be based on a flexible system, independent of external factors, and be able to switch from one form to another, creating new structural composition of different transport subsystems. The main goal of a flexible structure forwarding system is approaching the capabilities of its various elements, thereby ensuring technological continuity and compatibility of various units of the system. The basis of such constructions should be not only financial and economic criteria that allow Forwarding System achieve its objectives with the most efficient and effective criteria and technical and technological cooperation. 


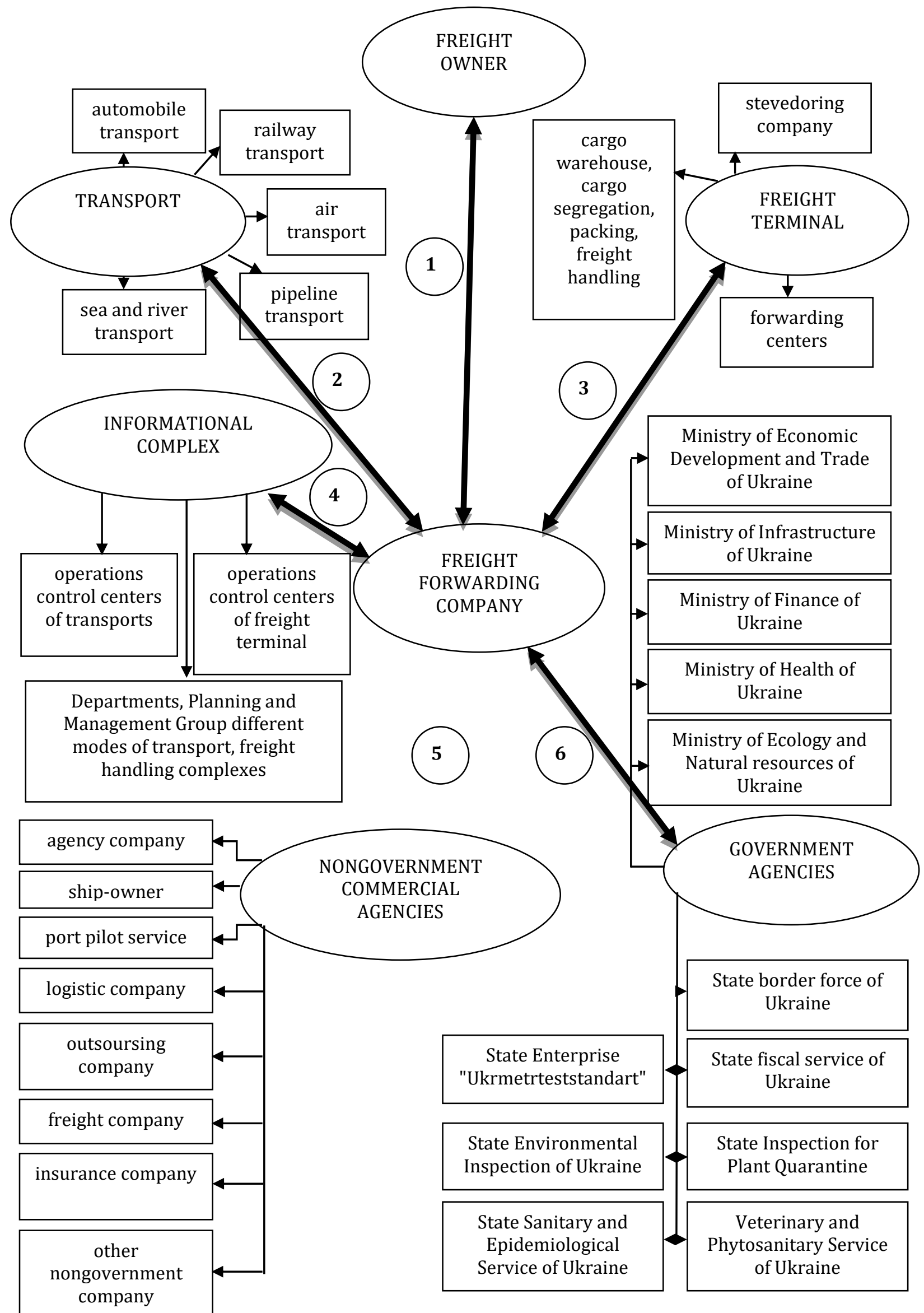

Fig. 1. Principle scheme of the interaction of freight-forwarding companies with elements of freightforwarding system 
Quality forwarding system depends not only on the level of quality of functioning of each participant, but also the degree of synchronization of their interaction in meeting customer needs. During the interaction of participants forwarding system should understand the presence of certain kinds of links that are found in the implementation system functions. This interaction has the following main forms:

- technological cooperation, unity evident in the technological operation system participants, includes such aspects as agreed and rational utilization of rolling stock, loading - unloading mechanisms, means consolidation and other tools. The solution of this problem is in close -called ' communication with developing common technology implementation transport - forwarding services ;

- Technical cooperation is manifested in two forms. The first type - a line of means used, the transport characteristics of cargo. Type of vehicle used: containers, loading - unloading mechanisms and storage facilities , should provide efficient handling of cargo . The second type of technical interaction - This line of technical operational parameters of technical means on places junction. The lack of technical interactions ( mismatch type of movable part of ways implementation loading - unloading works ; various sizes body, platform wagon , cargo compartment and etc.; discrepancy on power, duty machines and etc.) can cause the system or to inability joint operation, or to incomplete using available resources.

- Information interaction is manifested in the availability and relevance of all information necessary participants forwarding system;

- organizational and managerial interaction is manifested in actual and effective decision-making system for the organization and management of transport process not only in the long term, but also in real time;

- Economic cooperation is manifested in the sustainable use of financial, human and technical resources to optimize the cost of goods, particularly transportation costs;

- legal cooperation is manifested in the implementation of activities by the forwarding system in accordance with the laws of Ukraine and other countries.

Analysis of freight forwarding companies showed that at present there is no single approach to the development and study certain alternative delivery and choosing the best ones, which significantly increases the time spent on processing orders for freight forwarding services and, basically, is the cause errors and inaccuracies in the transport - forwarding process.

The solution of this problem is possible if make deeper analysis of interaction processes in freight forwarding system and modeling of these processes.

\section{Discussion of the results}

The main task of forwarding activities are timely, quality and complete satisfaction of providing cargo forwarding services on organization and transport of export, import, transit or other goods. With the expansion of the list of forwarding services the number of relationships is much more complicated due to the greater number of services between the parties forwarding system. Thus, the system of relations between the parties forwarding business is complicated and multi due to the relationships between them.

\section{Conclusions}

In the analysis were classified freight forwarding activities by type of service. The basic concepts and elements of the main types of cooperation in transport-forwarding system. Revealed the need for a deeper study of patterns of interaction in transport-forwarding system.

\section{Appendix A. Supplementary material}

Supplementary data associated with this article can be found, in the online version, at http://jsdtl.sciview.net

\section{Funding}

The authors received no direct funding for this research.

\section{Citation information}

Popovych, P., Shyriaieva, S. \& Selivanova, N. (2016). Analysis of the interaction of participants freight forwarding system. Journal of Sustainable Development of Transport and Logistics, 1(1), 16-22. doi: 10.14254/jsdtl.2016.1-1.3. 


\section{References}

Antonov, A. (2004). Systems analysis. Moscow: Higher School.

Hryhorak, M., \& Kotsyuba, V. (2006). Market analysis logistic services in Ukraine. Logistics: problems and solutions, 2(3), 21-25.

Jan, E. \& Kiryukhina, O. (2005). Forming forwarding services of logistics center. Economy and Management: Coll. Science. pr. KUETT, 7, 19-27.

Levkovets, P. (2003). Problems of implementation of transport forwarding activities in Ukraine. System management methods, technology and organization of production, operation and repair of cars: Journal, 17, 96-101.

Nagornyy, E., \& Naumov, V. (2009). The development and current state of forwarding services for enterprises and organizations in Ukraine. Bulletin of Kharkov National Automobile and Highway University, 44, 63-67.

Nagornyy, E., Ribanov, G., \& Chernish, N. (2002). Fundamentals transport forwarding and service enterprises, organizations and people. Kharkiv, Ukraine: KhNAHU.

Nagornyy, E. (2003). The current state of Ukrainian market of forwarding services and ways to reform. Bulletin of Kharkov National Automobile and Highway University, 23, 39-42.

Naumov, V. (2009). Range of forwarding services enterprises in road transport. Eastern-European Journal of Enterprise Technologies, 2/3(38), 33-35.

Popovych, P. (2016). Analitychni tehnologiyi v zabezpechenni ekonomichnoyi efektyvnosti logistychnyh system. Herald of HNTUSG, 169, 223-225.

Popovych, P., Shevchuk, O., Matviyishyn, A., \& Lototska, V. (2016). Doslidzhennia tendentsii rozvytku rynku vantazhnykh perevezen $\mathrm{v}$ suchasnykh umovakh [Study market trends of road freight transport in modern conditions]. Journal of Zhytomyr State Technological University, 2(77), 224-228.

Shanova, S., Popova, A., \& Gorev, A. (2011). Freight forwarding maintenance. Moscow, Russia: Publishing Centre "Academy".

Shyriaieva, S., \& Selivanova, N. (2014). Research the current state of the transport services market in Ukraine. Herald of National Transport University, 29(1), 354-361.

Shevchuk, O. (2016). Vplyv pokaznykiv efektyvnosti na bezpeku ruhu vulychno-dorozhnymy merezhamy. Herald of HNTUSG, 169, 205-209.

The Civil Code of Ukraine (2015). Kyiv, Ukraine: CUL Publishing.

The Law of Ukraine "On the freight forwarding activities". (2004, August 13). Official Bulletin of Ukraine, 30, 1.

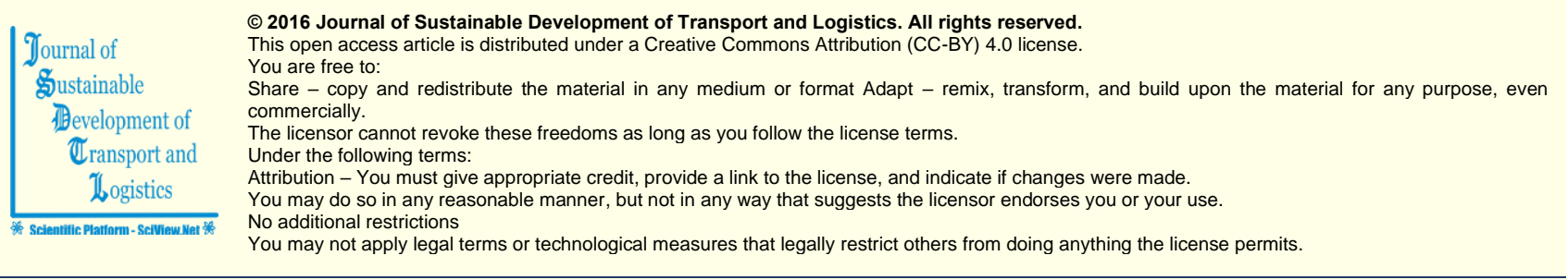

Journal of Sustainable Development of Transport and Logistics (ISSN: 2520-2979) is published by Scientific Publishing House "CSR", Poland, EU and Scientific Publishing House "SciView", Ukraine

Publishing with JSDTL ensures:

- Immediate, universal access to your article on publication

- High visibility and discoverability via the JSDTL website

- Rapid publication

- Guaranteed legacy preservation of your article

- Discounts and waivers for authors in developing regions

Submit your manuscript to a JSDTL at http://jsdtl.sciview.net/ or submit.jsdt|@sciview.net 